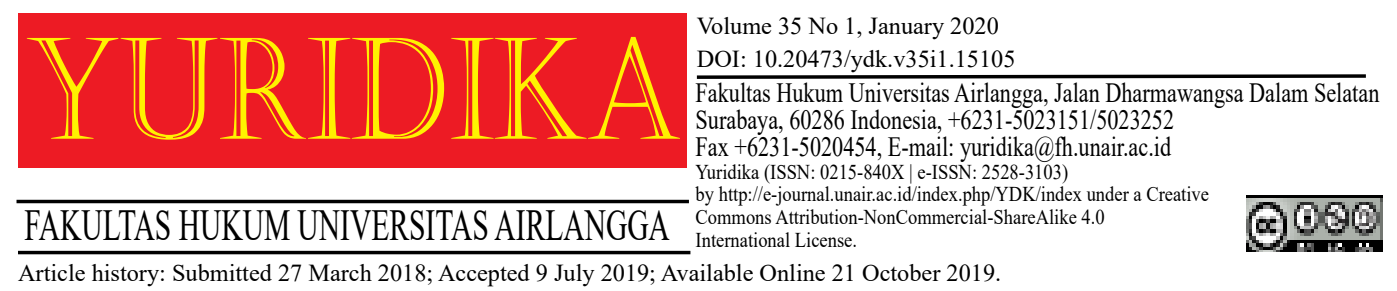

\title{
Characteristics of Party Autonomy in a Transnational Electronic Consumer Contract
}

\author{
Moh. Ali and Agus Yudha Hernoko \\ alifirmansyah2013@gmail.com \\ University of Jember
}

\begin{abstract}
International contracts involving legal subjects between countries will affect the law chosen by the parties. Electronic contracts are different than conventional contracts in general. Prominent characteristics includevirtual, paperless and borderless. Determination of legal choices cannot be made with a link-point approach that is generally applicable to conventional transactions. The typical e-commerce characteristics should be special treatment for special contracts. The virtual nature that knows no national borders is difficult to determine in which country the legal event takes place. Paperless nature often overrides accuracy in transactions, especially with regard to legal choice clauses and forum choices.In addition, another character is that electronic transactions are made in standard form and are arranged for the purpose of take or leave it. Generally, business actors have determined the choice of law and the choice of the forum. Electronic contracts place consumers in a weak bargaining position (the weaker party). There are active limitations in determining the legal choice clause, causing consumers not to have an unequal bargaining power, giving rise to a fundamental paradigm shift in the principle of freedom of contract from "party autonomy" to "one-sided autonomy". On this basis, the need for state intervention to provide legal protection in the form of mandatory regulations as an exception to the contractual principle that is absolute becomes relative, namely that the applicable law is not mutatis mutandis law that is chosen by the parties but the law where habitual residence is.

Keywords: ConsumerProtection; Choice ofLaw; Habitual Residence; Characteristic
\end{abstract}

\section{Introduction}

The presence of a free market results in the territorial boundaries of a country no longer being an obstacle in business activities that are based on one particular national law while also having a foreign element. ${ }^{1}$ The development of

\footnotetext{
1 Moch. Isnaeni, Perkembangan Hukum Perdata Di Indonesia (Laksbang Grafika 2013).[20].
} 
globalized, transnational e-commerce transactions will have a major impact on national economic growth; therefore, Indonesia cannot ignore the influence of interdependent economic and business relations between countries in regard to contract laws beyond national borders. ${ }^{2}$

International contracts involving two or more parties with different nationalities will involve two different states' legal systems, so it will bring consequences to the party's autonomy in choosing the law that applies to the contract made. Each country has different substantive laws ${ }^{3}$ and wants the contracts made to be subject to the law in their home country. ${ }^{4}$ In the context of transnational contracts, each country will try to protect its public policies by implementing restrictions on the autonomy of the other parties. ${ }^{5}$

Based on statistical data, consumer-based electronic contracts experience significant growth that affect the national economy. Some research results show that the growth of internet users in Indonesia reaches 19\% per year, and Indonesia is predicted to become the country with the largest economic in Southeast Asia. The population of internet users is growing rapidly in the world and is projected to reach 215 million before 2020, which was only 92 million in 2015. Indonesia's e-commerce opportunities will reach 52\% in the Southeast Asia region in 2025. Increased internet access is predicted to grow 39\% per year from 1.7 billion dollars US 2015 to 46 billion US dollars in 2025.

a. ICD predicted the e-commerce market in Indonesia to grow $42 \%$ from 2012 2015. This figure is higher than other countries such as Malaysia (14\%), Thailand (22\%), and the Philippines (28\%).

b. The 2015 Online Shopping Outlook Research revealed the value of online shopping in 2014 reached USD 21 trillion.

c. Data from the Indonesian Internet Service Providers Association (APJII) in

2 Manfred B Steger, Globalism, The New Market Ideology,(Globalisasi, Bangkitnya Ideologi Pasar) (Penerjemah: Heru Prasetia ed, Pustaka Lafadi 2006).[38].

3 Taufiqurrahman, Karakter Pilihan Hukum, Kajian Tentang Lingkup Penerapan The United Nations Convention on Contract for International Sale of Goods (CSIG) 1980 (Banyumedia 2010).[1].

${ }^{4}$ Gunawan Widjaja, Transaksi Bisnis Internasional-Ekspor Impor Dan Imbal Beli (RajaGrafindo Persada 2000).[1].

${ }^{5}$ Maryke S. Nuth, Party Autonomy, Choice of Law and Wrap Contracts (Faculty of Law University of Oslo 2012).[6]. 
January 2016 shows Indonesian internet users reached 88.1 million and $48 \%$ were daily internet users.

d. Research by Markplus Insight and Marketeers online magazine in 2013 showed that of 74.6 million internet users in Indonesia, 20\% were shopping online.

e. McKinsey's 2016 study shows that Indonesia is the third largest country thathad an increase in the popularity of mobile shopping (m-commerce), the first and second positions were occupied by China and India. Indonesia's e-commerce market is estimated to reach 130 billion US dollars in 2020 with a growth rate of $50 \%$ per year. The government is now making e-commerce the backbone of the digital economy.

E-commerce transactions will have an impact on the difficulty of determining the jurisdiction of parties. The determinant factors that cause difficulties in e-commerce dispute resolutions related to the choice of law are the characteristics that are virtual(cyber), paperless, and borderless and which distinguish them from conventional transactions.Consumer contracts electronically use media in the form of virtual devices, or websites, where transactions do not bring parties together face to face. Determination of legal choices cannot be made with a link-point approach that is generally applicable to conventional transactions. The typical e-commerce characteristics should be considered with special treatment for contracts such as this consumer contract. Since transactions occur in a virtualworld that knows no national borders, it is difficult to determine in which country the legal event took place. Paperless nature often overrides accuracy in transactions, especially with regard ofchoice of law clauses and choice of forum. Most of electronic transactions that occur are standard and arranged for the take or leave it. Business people generally have determined beforehand the choice of law and the choice of the forum, for example Amazon.com.

Contracts made in consumer transactions electronically place consumers in a weak bargaining position (the weaker party). Associating with party autonomy, consumers are in a disadvantaged position to negotiate terms in contracts and have difficulties in understanding complex provisions so as to reduce protection for consumers. ${ }^{6}$ There are

${ }^{6}$ ibid. [10].According Nuth "consumers have a difficulty to understand the complex terms of the contract which may deprive the consumer protection by implementing the governing law that is more favorable for businesses to pursue their commercial interests". 
active limitations in determining the choice of law clause, causing consumers not to have anunequal bargaining power, $^{7}$ giving rise to a fundamental paradigm shift in the principle of freedom of contract from "party autonomy" to "one-sided autonomy".

Based on the above statement, it is evident that the issue of dispute resolution in electronic transactions has not yet obtained firm, fair and definite legal certainty. The state must be present and impose interventions by providing regulations that become a stepping stone in the context of transnational consumer protection. These restrictions are determined by the social and economic conditions of modern life such as consumer protection, prevention of abuse of authority from economic authorities, and maintaining a climate of fair competition in a free market economy. ${ }^{8}$ Legal arrangements are useful for creating the level of legal certainty needed in business transactions and protecting the interests of the parties from the aspect of justice, in addition to providing the greatest benefit in all matters. This is in line with the philosophy and purpose of the law, namely to realize legal certainty, justice and expediency. Legal mechanisms need to be developed to make electronic transactions efficient and safe, as well as legally fostered. The background of the above conditions is important to study the problems in this paper are Characteristics of autonomous parties in transnational e-consumer contracts.

\section{Party Autonomy}

Party autonomy, the autonomy of the parties is interpreted as the flexibility of parties to determine the laws that apply to the contracts they make. Determination of applicable law is often interpreted as "choice of law." Party Autonomy is an important part of the principle of freedom of contract. This principle is the philosophical basis for the norms of contract law that open the broadest possible

\footnotetext{
7 Timothy P. Lester, 'Globalized Automatic Choice of Forum: Where Do Internet Consumers Sue? Proposed Article 7 of the Hague Convention on International Jurisdiction and Foreign Judgments in Civil and Commercial Matters and Its Possible Effects on E Commerce 432].' (2003) 9 University of Houston Law Center, New Eng. J. Int'1 \& Comp. L.[432].

8 Yansen Dermanto Latip, 'Pilihan Hukum Dan Pilihan Forum Dalam Kontrak Internasional' (Hukum Universitas Indonesia 2002).[64].
} 
parties to regulate themselves or determine their own laws that apply to contractual legal rights and obligations in order to accommodate, facilitate and protect the interests of the parties in the contract, with restrictions not contradictory with compelling laws, public order and decency. ${ }^{9}$ There are five principles contained in transnational freedom of contract including: first, being free in determining the contents of the contract; second, the form of the contract that depends on both parties; third, the binding element of the parties; fourth, there is an enforceability as an exception; fifth, and, the international nature and objectives of UNIDROIT principles that remain must be considered in the interpretation of the contract. ${ }^{10}$

According to Isnaeni, at the domestic level, the principle of freedom of contract is referred to in Article $1338 \mathrm{BW}$ as the freedom of the parties to contract. This freedom includes 5 (five) main things, namely: the freedom to make or not make a contract, the freedom to determine with whom he is contracting, the freedom to determine the form of contract, the freedom to determine the extent of contract content, and the freedom to determine the potential dispute resolution forum to occur later in the day. ${ }^{11}$ Whereas,onthe international stage, the freedom of the parties is referred to as party autonomy, which basically concerns 2 (two) things, namely thechoice of law and thechoice of forum. ${ }^{12}$

The choice of law in English literature is often called the freedom of contract or liberty of contract. In different legal traditions, different expressions are used such as in English Commmon called the proper law of the contract, governing law or aplicable Law. There are also those who call PartijAutonomie or de autonomie van partijen(Netherlands), Contratto in Collagamento (Italy), autonomie de la

\footnotetext{
9 Muhammad Syaifudin, Hukum Kontrak, Memahami Kontrak Dalam Perspektif Filsafat, Teori, Dogmatik Dan Praktik Hukum (Manda Maju 2012).[29].

10 Marcin Szwed, 'Contitutional Protection of Freedom of Contract in the European Union, Polan and the United States and Its Potential Impact on European Contract Law' (Central European University 2014).[8].

11 Moch. Isnaeni, Pejar Pendar Hukum Perdata (Revka Petra Media 2016).[77-78].

12 ibid.
} 
volonte (France) or intention of the parties (UK.) ${ }^{13}$ Other terms are also found such as Rechtskeuze, Rechtwahl, Choice of Law and Connecting Agreement. Heck calls it private autonomy, namely the right of individuals to determine something specifically in accordance with their wishes in their legal relations, insofar as it does not conflict with public order. ${ }^{14}$ Freedom of contract can be interpreted as a contract made by a legal subject where parties can approve or reject the contract. Whereas Party Autonomy can be interpreted as a choice of law that allows parties to choose certain state laws to determine their contracts by involving two or more jurisdictions.

According to some experts, the term Party Autonomy is often misinterpreted (misled), ${ }^{15}$ giving rise to thoughts in the actual direction not included in the term. This term contains the definition of determining the law that applies to the parties. Even though legally, the parties do not have the ability to make laws themselves. There is no authority to create laws for those who contract, but the parties are only given the freedom to choose which law is desired in the contract made. Kolleewijn stated "Het is slechtskiesvrijheid ...niet het recht tot self regeling"(that is the freedom to choose, not the right to self-regulate. ${ }^{16}$

M. Sumampouw tends to call the choice of law a point of connection. This term is considered more appropriate because it shows the content or substance from the point of connection, that is, the parties are given the power to choose a certain law that will control the contract they hold. ${ }^{17}$ In the process of determining the law, the parties are given autonomous function. The intention of the parties is the only factor authorized by HPI to determine the applicable law. So far, there is an assumption that the choice of law is an agreement that contains only the method of resolving disputes. The choice of law is often fostered by a choice of law clause as

13 Sudargo Gautama, Hukum Perdata Internasional (Jilid II, Alumni 2004).; Sutan Remi Sjahdeini, Kebebasan Berkontrak Dan Perlindungan Yang Seimbang Bagi Para Pihak Dalam Perjanjian Kredit Bank Di Indonesia (Pustaka Utama Graffiti 2009).[22].

${ }_{14}$ Sutan Remi Sjahdeini (n 13).[42].

15 Sudargo Gautama (n 13).

16 Abdul Gani Abdullah, 'Pandangan Yuridis Conflict of Law Dan Choice of Forum Dalam Kontrak Bisnis Internasional' (2005) 2 Bulletin Hukum Perbankan dan Kebanksentralan.[3].

17 M. Sumampouw, 'Pilihan Hukum Sebagai Titik Pertalian Dalam Hukum Perdjanjian Internasional' (Universitas Indonesia 1968).[22]. 
if only limited to the issue of legal choice clauses, even though the choice of law clause itself is one of the many issues relating to the choice of law. ${ }^{18}$

\section{Universal Views of the Principles of Autonomy for Parties}

According to Otto Sandrock, the principle of autonomous party has been recognized by almost all legal systems of countries in the world. ${ }^{19}$ In the doctrine of conflict of laws, David G Pierce stated that the freedom of the parties to choose a proper law to regulate their contracts is fair and appropriate. In principle, all national legal systems in the world are the same and therefore can be exchanged. ${ }^{20}$

The rule of law that provides regulation or settlement is actually part of a particular national legal system. There is almost no Private International Law (HPI) that applies to all countries in the world because it is one component of a legal system that is owned by every country in the world. This is the possibility of cheating the HPI that is said to be national but not for international. ${ }^{21}$ "Every country has its own international (private) law. This issue is the basis of difficulties in understanding a juridical international business contract. ${ }^{22}$

The teachings of the freedom of law by the parties were first introduced in the 16th century by Dumoulin in response to the dissatisfaction in the determination of applicable laws based on objective points of connection. The objective point of connection is too rigid and does not provide space for the free will of the parties, therefore subjective theories emerge which emphasize party autonomy. The parties have the freedom to regulate and choose the law in their contracts (the parties' freedom to choose the applicable law). ${ }^{23}$ Dumoulin softens the point of connection on the parties' will or party autonomy. He was the first to give a strict formula for the idea of freedom of parties, so it was called the fondateur de ladoctrine, a pioneer

\footnotetext{
18 Taufiqurrahman (n 3).[44].

19 Yansen Dermanto Latip (n 8).[10].

${ }^{20}$ ibid.

21 Moch. Isnaeni (n 11).

22 Sophar Maru Hutagalung, Kontrak Bisnis Di Asean, Pengaruh Sistem Hukum Common Law Dan Civil Law (Sinar Grafika 2013).[8].

${ }^{23}$ Taufiqurrahman (n 3).[231].
} 
in using the doctrine of the will of the parties as a point of connection.

This doctrine increasingly developed in the 19th century and was used by judges in legal considerations in order to decide cases. According to Savigny, legal relations are displayed in the form of voluntary submission to certain legal systems that occur because they are chosen (lex loci executions). ${ }^{24}$ Such choices mainly occur secretly. This theory was also developed by Mancini who stated that the autonomy of the parties is one of the overall rights of the HPI building in addition to the principle of nationality and public interest. ${ }^{25}$

Mancinicreatedindividual freedom to determine the law for their contractual relationship, but that freedom was limited by the understanding of public order. ${ }^{26}$ Caleb called public order the main limitation of freedom to carry out one's willingness in the field of contracts to avoid legal smuggling. ${ }^{27}$ Legal smuggling is an unechterechtswahl category, namely shifting from an objective linking point of connection such as making a change in domicile or going abroad to close a contract or choosing a place to execute a contract (lex loci executionis) abroad. ${ }^{28}$

There are several strong reasons from the efficiency point of view for law enforcement and the application of legal choice clauses in contracts including: ${ }^{29}$

1. choice of law as a means of avoiding legal provisions that force inefficiency;

2. raises juridical (forum shop) competition between countries;

3. useful as the development of further efficiency in the provisions of the standard form of an agreement;

4. functions as a problem solver in various legislations;

5. reduce uncertainty about the application of which law applies.

\section{Characteristics of Party Autonomy in Transnational Electronic Consumer Contracts}

Characteristics are grammatically interpreted as "having special characteristics in accordance with certain characteristics". There are also those who interpret

\footnotetext{
${ }^{24}$ Abdul Gani Abdullah (n 16).[4].

25 ibid.;Sudargo Gautama (n 13).[25].

${ }^{26}$ Abdul Gani Abdullah (n 16).; Sudargo Gautama (n 13).[6].

27 Sudargo Gautama (n 13).

28 ibid.[20].

${ }^{29}$ Yansen Dermanto Latip (n 8).[11].
} 
"distinguishing features," "certain qualities or traits," or "distinctive characteristics of someone or something." When it is associated with legal characteristics, these characteristics are not limited to meaning but also to principle.

As explained earlier, the distinguishing character of the autonomous parties in transnational electronic consumer contracts differs from the characteristics of conventional contracts in general. Character differences will certainly have implications for meaning and treatment. Special characters are also ideally treated specifically. Special characters cannot be treated in general.

Some characteristics of the parties' autonomy in transnational electronic consumer contracts have been partially explained in the previous section, including when the authors analyze the concept of justice associated with this electronic consumer contract. But in order for a thread to be drawn against the characteristics of autonomous parties in electronic consumer contracts, the following matters can be stated:

In the aspect of the relationship between consumers and business actors, the consumer contract has an unequal bargaining position;

Imbalance is caused by several things, including, business people have contracted with consumers through standardized contracts. The contract in the form of a standard contract or standard contract creates an imbalance in the autonomy of the parties because the clauses are made in a predetermined form. ${ }^{30}$

"Standard contracts are typically used by enterprises with strong bargaining power. The weaker party, in need of the goods or services, is frequently not in a position to shop around for better terms, either because the author of the standard contract has a monopoly (natural or artificial) or because all competitors use the same clauses. His contractual intention is but a subjection more or less voluntary to terms dictated by the stronger party, terms whose consequences are often understood only in a vague way, if at all".

The buyer or consumer does not have a bargaining position or has a weak bargaining position to negotiate because the standard contract is designed in an electronic system so that there is no choice for consumers to negotiate the clause, therein

\footnotetext{
${ }^{30}$ Friedrich Kessler, 'Contracts of Adhesion-Some Thoughts About Freedom of Contract' [1943] Columbia Law Review ,Yale Law School Faculty.[632].
} 
including not limited to determining legal choices. In the use of standard contracts/ standard clauses, the freedom to enter into contracts and give agreements to these contracts is not carried out as freely as agreements made directly by involving the parties in negotiating the agreement clause. ${ }^{31}$

The clause in the electronic contract includes the choice of law, generally made in the form of writing made small (small print letter), so it is not clear and not easily understood by consumers. Active consumer limitation in determining legal choice clauses causes consumers not to have a balanced and fair bargaining position (unequal bargaining power) ${ }^{32}$ The seller has a higher position and is more dominant because he chooses the law first without clear notification. Consumers do not have a position to understand complicated clauses and standards, causing sellers tend to abuse their dominant position for their business interests. Inequality and imbalance of the parties in conveying the common will to determine contract clausesraises a fundamental paradigm shift in the principle of freedom of contract from "party autonomy" to "one sided autonomy."

Such a paradigm raises injustices in contracts, and the freedom of the parties is only limited to abstract jargon and not grounded as the interests built into the parties' contracts. Norberth Reich stated that the problem often faced by consumers was the attitude of business actors who acted fraudulently when the sale and purchase agreement was carried out, such as unclear content of standard contracts, defective products, and unsatisfactory services, misleading advertisements and after-sales service issues. ${ }^{33}$

Edmon Makarim said that some of the problems that arise related to consumer rights include: ${ }^{34}$

\footnotetext{
${ }^{31}$ Ahmadi Miru and Sutarman Yodo, Hukum Perlindungan Konsumen (1st edn, Raja Grafindo Persada 2014).[19].

${ }^{32}$ Timothy P. Lester (n 7).[432].;Maryke S. Nuth (n 5).[10].

${ }^{33}$ Norberth Reich, Protection of Consumers Economis Interest by the EC (Sydney Law Review 1992).[24-61].

${ }^{34}$ Edmon Makarim, Pengantar Hukum Telematika Suatu Kompilasi Kajian (Raja Grafindo Persada 2005).[312].
} 
1. Consumers cannot directly identify, see, or touch the ordered goods;

2. Unclear information about products (goods and services) offered and/or there is no certainty whether consumers have obtained various information that is worthy of being known or which should be needed to make a decision in contract;

3. It is unclear the legal status of the business actor;

4. There is no guarantee of contractual security and privacy as well as an explanation of risk regarding the system used, especially in terms of electronic payments either through credit cards or electronic cash;

5. Unbalanced risk exemption, because generally towards buying and selling on the internet, payment has been paid in advance by the consumer while the goods are not necessarily received or followed later because the guarantee is a guarantee of the delivery of goods not receipt of goods;

6. Contracts that are borderless raise questions about which state jurisdiction should be enforced.

Because it has been standardized, the consumer does not have any other option than to take or not to contract or agreement (take it or leave it). Some experts argue that such contracts are referred to as adhesion contracts because the conditions have been unilaterally determined by the strong and consequently burdensome to parties that are relatively weaker;hence, the agreement is debated about its validity. ${ }^{35}$ The nature of the adhesion contract is that the contract is not a product of bargaining because it contains content originating from one party's control before printing (the pre-printed terms of one-sided control). ${ }^{36}$ One form of the standard clause is the exoneration clause, namely a clause that contains conditions that limit or even completely erase the responsibility that should be borne by the producer or business actor. Engels argues that there are at least three juridical forms which include the exoneration clause, namely; ${ }^{37}$

1. Reduction or elimination of liability for legal consequences due to lack of good implementation of the agreement;

2. Limitation or elimination of own obligation;

3. Creation of obligations which are then charged to one party.

\footnotetext{
${ }^{35}$ Herlien Budiono, Asas Keseimbangan Bagi Hukum Perjanjian Indonesia, Hukum Perjanjian Berlandaskan Asas Asas Wigati Indonesia (Citra Aditya Bakti 2015).[32].

${ }^{36}$ Mo Zhang, 'Contractual Choice Of Law In Contracts Of Adhesion And Party Autonomy' [2015] Akron Law Review.[124].

${ }^{37}$ R.H.J Engels, Syarat Syarat Eksonari Atau Syarat Syarat Untuk Pengecualian Tanggung Jawab, (Copendium Hukum Belanda) (Leiden 1978).[159-192].
} 
According to Sluitjer, the standard agreement is not an agreement because the position of the business actor in the agreement acts as if it were the legislator of the private sector (legio particulate wetgever). ${ }^{38}$ The conditions required by the business actor in the agreement are laws not agreements. ${ }^{39}$ This issue concerns the use of many standard agreements in the business world, namely regarding the inclusion of exoneration clauses. An exoneration clause is a condition that specifically frees the employer from the responsibility for the adverse consequences arising from the implementation of the agreement.

According to Mariam DarusBadrulzaman, the standard agreement is an agreement whose contents are standardized and set forth in the form of an agreement form. The standard agreement is contrary to the principle of freedom of contract which is responsibleIn the agreement the standard position ofbusiness actors and consumers is not balanced. A position dominated by business actors opens a wide opportunity abuse ofposition. Business actors only regulate their rights not their obligations. Standard agreements must not be allowed to grow wildly because they need to be regulated. Mariam DarusBadrulzaman defines it as an agreement in which the exoneration requirements are standardized and set forth in the form, with the following characteristics: ${ }^{40}$

1. Its contents are unilaterally determined by creditors whose position is relatively stronger than the debtor;

2. The debtor does not determine the contents of the agreement at all;

3. Encouraged by their needs, the debtor is forced to accept the agreement;

4. The form is written;

5. Prepared in bulk or individually.

6. The standard contract attaches to the weaker consumer besides having to agree to decide to take it or leave it. ${ }^{41}$

Unbalanced contracts have implications for injustices received by one party, especially consumers. As understood, the imbalance of position will lead to a legal

38 ibid.[109].

${ }^{39}$ Amrul Partomuan Pohan, Penggunaan Kontrak Baku (Standard Contract) Dalam Praktek Bisnis Di Indonesia, Dimuat Dalam Majalah Hukum Nasional (BPHN, Departemen Kehakiman 1994).[64].

${ }^{40}$ Abdul Gani Abdullah (n 16).[50].

${ }^{41}$ Yansen Dermanto Latip (n 8).[436]. 
gap regarding the rights and obligations of the parties. The dominance of one party has derailed the position of the other party in a position that does not benefit him. The aspect of justice in contracted freedom is derived from a concept that places the agreement of the parties as part of law or law. This principle was born along with the development of the contractual relations of the parties which were guaranteed by the law as supremacy and incarnated as a law for those who made it. This principle is almost recognized by all countries, including Indonesia, which is then followed in the provisions of Article 1338 paragraph (1) BW which states that all agreements made legally apply as laws for those who make them.

To achieve the objectives of the freedom of contract principle, the parties to the agreement must have a balanced bargaining position. According to Pitney it is impossible to uphold freedom of contract without at the same time acknowledging the balance of bargaining. ${ }^{42}$ But in reality, the parties do not always have a balanced bargaining position, consequently, parties that have a stronger bargaining position tend to control those who have a weaker bargaining position. ${ }^{43}$ Between freedom of contract and the principle of consensualism in these conditions no longer becomes consistent, especially with the pretext of efficiency. Relatively strong parties are able to prepare early for a standardized contract design.

While according to Patrik S. Atiyah the basic assumption of the view of the doctrine of freedom of contract is that the bargaining position of the parties in the contract is equal. ${ }^{44}$ Every individual is autonomous and independent, equal among other individuals. In addition, there are similarities among other individuals, at least having equal autonomy and equal rights to be free from other individual interventions in exercising control over him. In the perspective of consumer protection there is an imbalance in the bargaining position of the parties. Consumer-producer relations are assumed to be sub-ordinate relationships, so consumers are in a weak position in the

42 Ridwan Khairandy, Itikad Baik Dalam Kebebasan Berkontrak (Program Pascasarjana, Fakultas Hukum Universitas Indonesia 2003).[31].

43 ibid. [2,32].

44 ibid.[33]. 
process of forming contractual wills.$^{45}$ According to Herlien Budiono in discussing the characteristics of balance requires that there be elements of equality between the parties. ${ }^{46}$ In the reciprocal agreement the quality of performance promised is reciprocal placed in the context of subjective valuation in a reciprocal manner and will be justified by the legal order. However, the agreement must be rejected if it appears that the factual position of one of the parties to the other party is stronger and unbalanced. This can affect the scope of content, intent and purpose of the agreement. The result of inequality of achievement in reciprocal agreements is imbalance. ${ }^{47}$ If the stronger position affects the achievement relationship with one another which will disrupt the balance of the agreement, then there is a reason for the aggrieved party to submit a claim for invalidity of the agreement. ${ }^{48}$ Factors that can disrupt the balance of the agreement include how to form agreements that involve unequal parties and or the inequality of promised performance achievements reciprocally. ${ }^{49}$

Electronic contracts that are virtual, paperless, borderless are closely related to the location or place where the contract occurs so that it is difficult to determine which law will apply to the contract. In addition to the virtual nature of electronic contracts according to Middleton and Jocelyn, the complexity of the application of internet jurisdictions includes the following: ${ }^{50}$

1. Material posted on the internet has worldwide audience;

2. There is an enormous and growing number of internet users' internationality;

3. It is easy to move a website from one jurisdiction to another;

4. A website can be hosted in one jurisdiction, but directed at users in another jurisdiction;

5. Parts of website may be hosted in one jurisdiction, while other parts of the website are hosted in another jurisdiction; and

6. It is not always possible to determine where a website a website or a user located.

${ }^{45}$ Agus Yudha Hernoko, Hukum Perjanjian, Asas Proporsionalitas Dalam Kontrak Komersial (LaksBang Mediatama Yogyakarta 2008).[13].

${ }^{46}$ Herlien Budiono (n 36).[318].

47 ibid.

48 ibid.

49 ibid.[319].

${ }^{50}$ Edmon Makarim (n 35).[526]. 
Because transactions are conducted through virtual media, it will be difficult to determine where the contract takes place. If it is related to which law applies to a conventional contract such as the lex loci contractus approach (where the contract is made) or lex loci solutionis (where the contract is implemented), then the electronic contract cannot be detected where the contract is made or the contract or even place the implementation of the contract, because according to what Middleton and Jocelyn conveyed on a website can be controlled from any part of the world and not physically bound. A website can be moved from one country to another. Websites can also come from somewhere, but can be controlled from other places from different jurisdictions, making it difficult to determine which state law will apply. Electronic contracts cannot be determined in which countries, because electronic contracts are not affiliated with the borderless country.

\section{Specific characteristics require special treatment.}

Synergy with the presentation that addresses the characteristics of consumer contracts as the weaker party with all its participation in the opportunities for the above injustices and virtual, paperless and borderless characteristics, increasingly confirms that transnational electronic consumer contracts have special characteristics that distinguish them from conventional contracts in general.As a precursor to this particular contract, there must also be special treatment for transnational electronic consumer contracts. This special treatment is related to determining the choice of law by the parties (party autonomy). As an analysis of the principle of party autonomy in conventional contracts or commercial contracts in general that imposes a doctrine that the determination of the law chosen by the parties is a law which has been chosen or determined in advance by the parties in the contract they made.

The application of the principle of freedom of contract and the principle of the principle of servitude in conventional contracts applies absolute and absolute. The absolute nature of the choice of law in the parties' contracts is set forth in the "choice of law clause" norm which has consequences for the judiciary to try to use the law that has been chosen by the parties. 
Provisions regarding the enactment of the earlier law have been stipulated in HIR Article 118 paragraph (4) whose free translation states that "If the letter is valid and a place of domicile is chosen, the plaintiff, if he likes, can submit the claim to the head of court country in whose jurisdiction is the chosen place of residence."

Article 142 paragraph (4) of the RBG states "if it has been agreed on a deed regarding legal domicile, then the petition for objection shall be submitted to the district court designated in the agreement"; These provisions are also regulated in Book II of the Implementation Guidelines and Administration of Courts in the Four Judicial Environments, Issue 2007 published by the Supreme Court of 2009, pages 50-51 concerning relative authority, stating that if there is a choice of domicile written in the deed, then the objection is submitted at the chosen domicile. The issue of determining the choice of law is always faced with the legal regime adopted by each country. Moreover, the problems in e-commerce contracts are not so easily approached by using the rules that apply in Private International Law. The increasingly globalized world development on the one hand has an impact on the importance of establishing laws specifically in e-commerce, but there are those who consider such actions not yet felt necessary because they can still be approached with the concepts and principles of the International Civil Law of each country.

The discussion of jurisdiction is becoming increasingly important, considering that traditional approaches based on geographical locations that have certain regional boundaries cannot be used to resolve disputes in the world of technology. ${ }^{51}$ This situation raises misuse of the situation by business actors towards consumers. Therefore, according to AzNasution, state interference is needed through the court by presenting considerations as the reason for the termination of the agreement which is often known as the misuse of circumstances (misbruik van omstandingbeden). ${ }^{52}$

Regarding the doctrine of the abuse of undue influence even though Indonesia does not adhere to this doctrine, the Indonesian courts also apply it especially in

\footnotetext{
51 ibid.[268].

52 Az Nasution, Hukum Perlindungan Konsumen, Suatu Pengantar (Diadit Media 2011).[120].
} 
consideration of its decisions. This doctrine states that if one party has a dominant position, then it can abuse its position and encourage the other party to enter into the contract. Domination can be psychological or economic, the misuse of circumstances in other terms is often referred to (misbruik van de omstandigheden). ${ }^{53}$ The new Dutch or NBW BurgerlijkWetboek is contained in the article about the doctrine of misbruik van de omstandigheden or abuse of circumstances or undue influence which results in the disability of an agreement and becomes the basis for demanding cancellation of the agreement.

\section{Conclusion}

A special characteristic of transnational electronic consumer contracts in relation to this autonomous party, the autonomy of the parties in making legal choices is no longer relevant based on the chosen law as is usual in conventional contracts in general. The imbalance in the bargaining position of consumers and businesspeople creates interventions by the state to provide legality and appropriate legal protection in order to provide fair and definite dispute resolution.

The legal gap between consumers and business actors cannot be allowed to become increasingly gaping, so freedom of contract and party autonomy in determining legal choices cannot be given as freely as without restrictions. The restrictions that can be given by the state are public policy and mandatory law.

Through a coercive principle, autonomous parties which originally apply the rule that applicable law is a law chosen by the parties, then specifically for transnational electronic consumer contracts, the state must be present to balance the inequality of the parties by providing minimum protection through the rules mandatory law, namely that the applicable law is the law in which habitual residence consumers.

More importantly, it is underlined that in the basic transnational electronic consumer contract, Pactasuntservanda, which is generally applicable in commercial

53 Suharnoko, Hukum Perikatan (Law Of Obligation), Hukum Kontrak Dalam Perspektif Komparatif (Pustaka Larasan 2012).[92]. 
contracts in general, is not absolute. The freedom or autonomy of the parties in determining the choice of law as outlined in the contract is fortified by a barrier wall, namely what is called Public Policy and mandatory law.

\section{Bibliography}

Abdul Gani Abdullah, 'Pandangan Yuridis Conflict of Law Dan Choice of Forum Dalam Kontrak Bisnis Internasional' (2005) 2 Bulletin Hukum Perbankan dan Kebanksentralan.

Agus Yudha Hernoko, Hukum Perjanjian, Asas Proporsionalitas Dalam Kontrak Komersial (LaksBang Mediatama Yogyakarta 2008).

Ahmadi Miru and Sutarman Yodo, Hukum Perlindungan Konsumen (1st edn, Raja Grafindo Persada 2014).

Amrul Partomuan Pohan, Penggunaan Kontrak Baku (Standard Contract) Dalam Praktek Bisnis Di Indonesia, Dimuat Dalam Majalah Hukum Nasional (BPHN, Departemen Kehakiman 1994).

Az Nasution, Hukum Perlindungan Konsumen, Suatu Pengantar (Diadit Media 2011).

Edmon Makarim, Pengantar Hukum Telematika Suatu Kompilasi Kajian (Raja Grafindo Persada 2005).

Friedrich Kessler, 'Contracts of Adhesion-Some Thoughts About Freedom of Contract' [1943] Columbia Law Review ,Yale Law School Faculty.

Gunawan Widjaja, Transaksi Bisnis Internasional-Ekspor Impor Dan Imbal Beli (RajaGrafindo Persada 2000).

Herlien Budiono, Asas Keseimbangan Bagi Hukum Perjanjian Indonesia, Hukum Perjanjian Berlandaskan Asas Asas Wigati Indonesia (Citra Aditya Bakti 2015).

M. Sumampouw, 'Pilihan Hukum Sebagai Titik Pertalian Dalam Hukum Perdjanjian Internasional' (Universitas Indonesia 1968).

Manfred B Steger, Globalism, The New Market Ideology,(Globalisasi, Bangkitnya Ideologi Pasar) (Penerjemah: Heru Prasetia ed, Pustaka Lafadi 2006).

Marcin Szwed, 'Contitutional Protection of Freedom of Contract in the European 
Union, Polan and the United States and Its Potential Impact on European Contract Law' (Central European University 2014).

Maryke S. Nuth, Party Autonomy, Choice of Law and Wrap Contracts (Faculty of Law University of Oslo 2012).

Mo Zhang, 'Contractual Choice Of Law In Contracts Of Adhesion And Party Autonomy’ [2015] Akron Law Review.

Moch. Isnaeni, Perkembangan Hukum Perdata Di Indonesia (Laksbang Grafika 2013).

—

Muhammad Syaifudin, Hukum Kontrak, Memahami Kontrak Dalam Perspektif Filsafat, Teori, Dogmatik Dan Praktik Hukum (Manda Maju 2012).

Norberth Reich, Protection of Consumers Economis Interest by the EC (Sydney Law Review 1992).

R.H.J Engels, Syarat Syarat Eksonari Atau Syarat Syarat Untuk Pengecualian Tanggung Jawab, (Copendium Hukum Belanda) (Leiden 1978).

Ridwan Khairandy, Itikad Baik Dalam Kebebasan Berkontrak (Program Pascasarjana, Fakultas Hukum Universitas Indonesia 2003).

Sophar Maru Hutagalung, Kontrak Bisnis Di Asean, Pengaruh Sistem Hukum Common Law Dan Civil Law (Sinar Grafika 2013).

Sudargo Gautama, Hukum Perdata Internasional (Jilid II, Alumni 2004).

Suharnoko, Hukum Perikatan (Law Of Obligation), Hukum Kontrak Dalam Perspektif Komparatif (Pustaka Larasan 2012).

Sutan Remi Sjahdeini, Kebebasan Berkontrak Dan Perlindungan Yang Seimbang Bagi Para Pihak Dalam Perjanjian Kredit Bank Di Indonesia (Pustaka Utama Graffiti 2009).

Taufiqurrahman, Karakter Pilihan Hukum, Kajian Tentang Lingkup Penerapan The United Nations Convention on Contract for International Sale of Goods (CSIG) 1980 (Banyumedia 2010).

Timothy P. Lester, 'Globalized Automatic Choice of Forum: Where Do Internet Consumers Sue? Proposed Article 7 of the Hague Convention on International Jurisdiction and Foreign Judgments in Civil and Commercial Matters and Its 
Possible Effects on E Commerce 432].' (2003) 9 University of Houston Law Center, New Eng. J. Int'l \& Comp. L.

Yansen Dermanto Latip, 'Pilihan Hukum Dan Pilihan Forum Dalam Kontrak Internasional' (Hukum Universitas Indonesia 2002).

HOW TO CITE: Moh. Ali and Agus Yudha Hernoko, 'Characteristics of Party Autonomy in a Transnational Electronic Consumer Contract' (2020) 35 Yuridika. 